Artvin Çoruh Üniversitesi

Orman Fakültesi Dergisi

ISSN:2146-1880, e-ISSN: 2146-698X

Yıl: 2019, Cilt: 20, Sayı:1, Sayfa:118-124

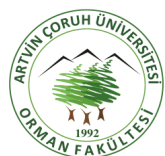

ofd.artvin.edu.tr
Artvin Coruh University

Journal of Forestry Faculty

ISSN:2146-1880, e-ISSN: 2146-698X

Year: 2019, Vol: 20, Issue: 1, Pages:118-124

(c) $(1)$

\title{
Bambudan nanofibril selüloz eldesi
}

\section{Nanofibril cellulose production from bamboo}

\section{Mahmut Ali ERMEYDAN DD, Onur AYKANAT iD}

Bursa Teknik Üniversitesi Orman Fakültesi Orman Endüstri Mühendisliği Bölümü Bursa, Türkiye

Eser Bilgisi/Article Info
Araştırma makalesi/Research article
DOI: 10.17474/artvinofd.487025
Sorumlu yazar/Corresponding author
Mahmut Ali ERMEYDAN
e-mail: mahmut.ermeydan@btu.edu.tr
Geliş tarihi / Received
23.11.2018
Düzeltme tarihi / Received in revised form
02.05.2019
Elektronik erişim / Online available
15.05.2019
Anahtar kelimeler:
Bambu
Işık mikroskobu
Nanofibril selüloz
Selüloz izolasyonu
Keywords:
Bamboo
Light microscopy
Nanofibrillated cellulose
Cellulose isolation

Cellulose isolation

\begin{abstract}
Özet
Bambu tropikal iklim etkisi altında bulunan alanlarda en önemli doğal kaynaklardan birisidir. Diğer lignoselülozik kaynaklarla karşılaştıııldığında yüksek verim ve düşük maliyete sahiptir. Nanoselülozun yüksek mekanik kuvveti, biyouyumluluğu, yüksek yüzey alanına sahip olması kompozit, gıda ve eczacılık gibi alanlarda kullanılma potansiyelini ortaya çıkarmış, ucuz kaynaklardan doğru metotlarla üretilmesi önem kazanmıştır. Bu çalışmada, ülkemizde de bulunabilen Forgesia nitida bambu türünden sülfürik asit yöntemiyle görünen ortalama $200 \mathrm{~nm}$ çaplarında selüloz nanofibrilleri elde edilmiştir. Öncelikle bambu selüloz liflerini izole etmek için sokslet ekstraksiyon yöntemiyle yağsı maddeler ve karışımda çözünen safsızlıklar sikloheksan (2:1) etanol kullanılarak 12 saatte ayrılmıştır. Alkali işlem için \%8'lik potasyum hidroksit kullanılarak lignin ve hemiselüloz uzaklaştırılmıştır. Katı madde \%10'luk asetik asit çözeltisiyle nötralize edilmiştir. Daha sonra TAPPI metoduna göre sodyum klorit ile tekrar ağartma işlemi uygulanmıştır. Selüloz nanofibrilleri 6,5M sülfürik asit çözeltisiyle 2 saatte $60^{\circ} \mathrm{C}^{\prime}$ de reflaks yapılarak üretilmiştir. Nanofibrillerin kimyasal özellikleri FTIR spektroskopisi, termal özellikleri TGA-DTG analizi, morfolojik özellikleri de ışık mikroskobu ile incelenmiştir.
\end{abstract}

\begin{abstract}
Bamboo is one the important bioresources under the tropical climate. It has high growth efficiency with a low cost between other lignocellulosic resources. It has become important to produce nanocelulose with the right methods and from economical sources that reveal its potential with its high mechanical strength, biocompatibility in the areas such as composites or pharmaceuticals. Cellulose nanofibers were obtained at an observable minimal of $200 \mathrm{~nm}$ by the sulfuric acid method of Forgesia nitida bamboo. First, bamboo was soxlet extrated with cyclohexane (2:1) ethanol for 12 hours to dissolve and remove the leachate and waxy materials. Then $8 \%$ of potassium hydroxide was used for alkaline treatment. The solid was neutralized with $10 \%$ acetic acid solution. Then, rebleaching with sodium chloride was applied according to TAPPI method. Cellulose nanofibrils were produced by refluxing at $60^{\circ} \mathrm{C}$ for 2 hours with $6.5 \mathrm{M}$ sulfuric acid solution. Chemical properties of nanofibrils were investigated by FTIR spectroscopy, thermal properties TGA-DTG analysis, light microscopy with morphological characteristics.
\end{abstract}

\section{GíRiş}

Bambu, selüloz liflerinin lignin matris içine gömülü olduğu doğal bir lignoselülozik kompozittir. Bambu liflerinin ortalama uzunluğu $2 \mathrm{~mm}$ ve ortalama çapı 10-20 $\mu \mathrm{m}$ 'dir. Bambunun kimyasal içeriği temelde selüloz, hemiselüloz ve ligninden oluşmaktadır. Bu temel bileşenler hücre çeperinin \%90-98'ini oluşturmaktadır. Diğer kalan \%2$10^{\prime}$ luk kısım ise düşük molekül ağırlıktaki ekstraktiflerdir. Bambu sapında \%60-70 holoselüloz, \%20-25 pentosanlar, ayrı ayrı 20-30\% oranlarında lignin ve hemiselüloz bulunmakla birlikte, eser miktarlarda rezinler, tanenler, yağlar ve inorganik tuzlar mevcuttur (Razak ve ark. 2013). Selüloz liflerinin mikrofibril açısı çok küçüktür ve bambu polilamellar duvar yapısına sahiptir (Şekil 1) (Imadi ve ark. 2014)

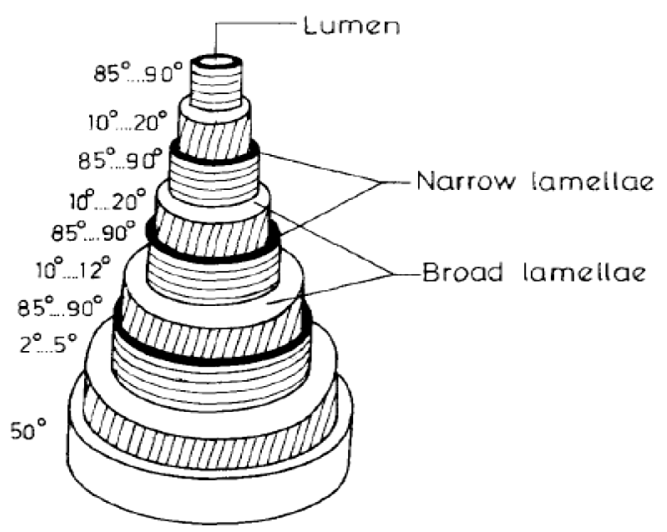

Şekil 1 Bir bambu lifinin polilamellar çeper yapısı modeli (Parameswaran and Liese 1981) 
Bu faktörlerden dolayı fiber yönünde bambunun darbe, çekme ve eğilme dayanımı yüksektir (Jain ve ark. 1999). Bambu hızlı büyüyen ve yüksek verimle yenilenebilir bir kaynaktır. Bambunun hızlı büyümesi kullanımı için önemli bir teşvik edici özelliktir. Bambu günde $15-18 \mathrm{~cm}$ büyümeyle 4-6 ayda maksimum yüksekliğine ulaşabilir. Kalın çeperleri ve uzun sapından dolayı bambu, un, lif, pul, cips gibi birçok partikül haline dönüştürülebilir. Bambunun yoğunluğu $0.4-0.9 \mathrm{~g} / \mathrm{cm}^{3}$ arasında anatomik yapısına göre değişiklik gösterir. Ağaca benzeyen bambu, heterojen ve anizotropik bir malzemedir. Bundan dolayı mekanik özellikleri mikroyapı özellikleri, sap uzunluğu, sap lokasyonu, yoğunluk ve nem içeriğiyle ilgili olarak son derece düzensizdir. Kopma direnci 50-120 MPa arasında değişebilirken, elastik modülü 1700-6300 $\mathrm{MPa}$ aralığındadır. Liflere paralel kesme direnci 4-14 $\mathrm{MPa}$ olabilirken, liflere paralel baskı direnci 24-70 $\mathrm{MPa}$ değerlerini gösterebilir (Pannipa 2013).

Nanoselüloz, bitkilerden veya bakterilerden elde nano boyutlu doğal selüloz olarak tanımlanmaktadır. Genellikle, nanoselülozlar 3 tür olarak ayrılırlar, selüloz nanokristaller (CNC), selüloz nanofibriller (CNF) ve bakteriyel nanoselüloz (BNC) (Tozluoğlu ve ark. 2015). CNC ve CNF çıkarma kaynakları ahşap, pamuk, kenevir, keten, buğday samanı, şeker pancarı, patates yumruğu, dut kabuğu, rami, vb.dir. Asit hidrolizi gibi kimyasal olarak oluşturulmuş yıkım stratejisi, doğal selülozdan CNC'nin çıkarılması, amorf bölgelerin uzaklaştırılması ve yüksek kristalin yapının korunması yoluyla yaygın olarak gerçekleştirilir. Yayılmış nanopartiküller (CNC) 5-30 nm çapında ve 100-500 nm uzunluğunda (bitkisel selülozundan) veya $100 \mathrm{~nm}$ uzunluğa kadar birkaç mikrometre (tunik ve yosun selülozlarından) uzunluklarda elde edilebilmektedir (Ning ve Dufresne 2014). Asit hidrolizi yanında, oksidasyon yöntemleri özellikle TEMPO oksidasyonu adı verilen yöntem CNF üretiminde yaygın olarak kullanılmakta ve mekanik parçalanma işlemlerinin süresini azaltarak homojenizasyonu sağlamak amaçlanmaktadır (Poyraz ve ark. 2018). Nanoselüloz, gıda, kağıt, ambalaj, farmasötik, aerojel olarak bir çok farklı kullanım alanı bulabilecek özelliklere sahiptir (Bardak ve ark. 2016).

Mevcut çalışmada ülkemizde peyzaj amacıyla kullanılan Forgesia nitida bambu türünden ilk defa nanofibril selüloz üretimi sülfürik asit metoduyla gerçekleştirilmiş, karakterizasyonu için de FTIR, TGA ve ışık mikroskobu kullanılmıştır.
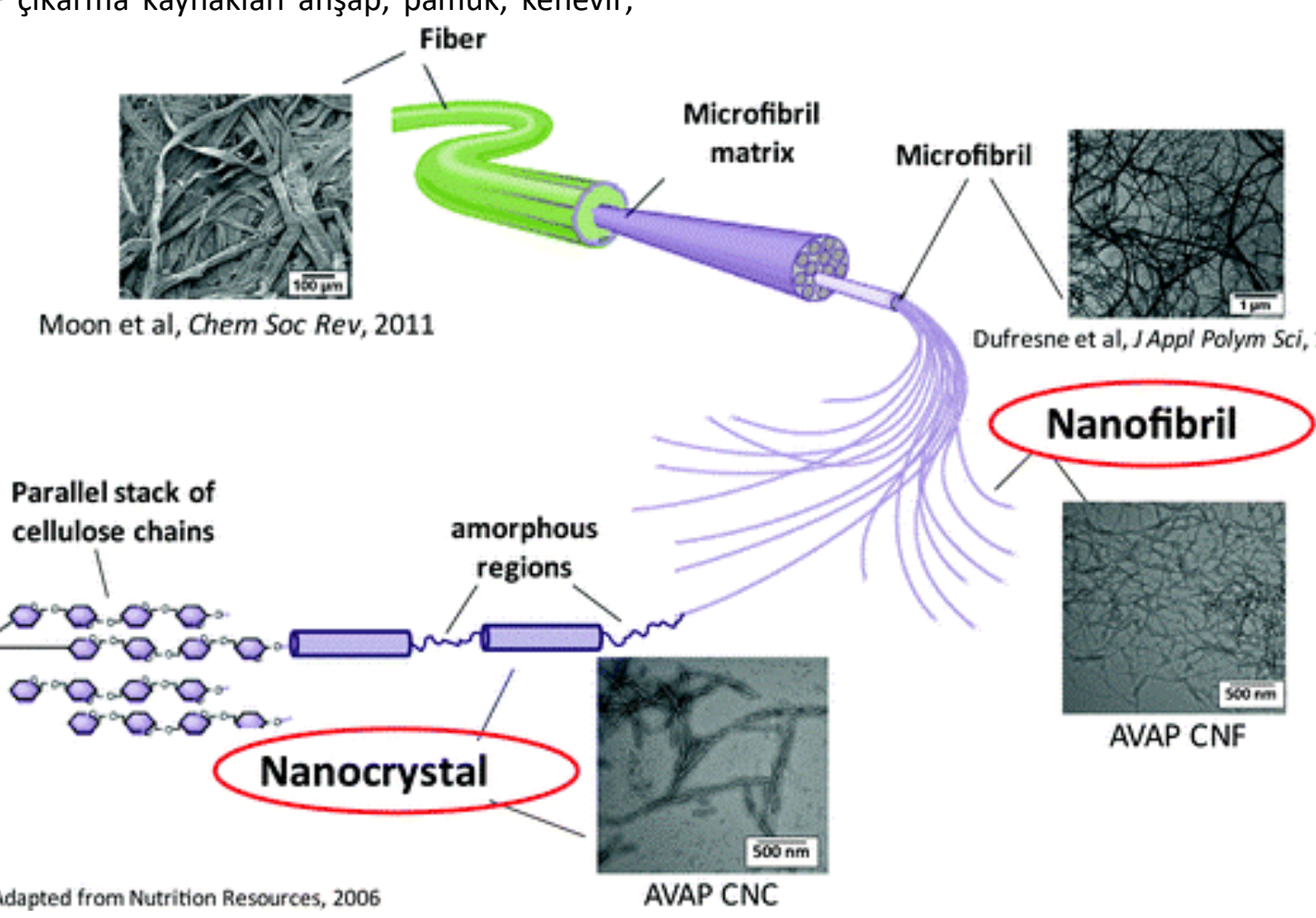

Şekil 2 Nanoselülozun hiyerarşik yapısı (Ning ve Dufresne 2014; Nelson ve ark. 2016) 


\section{MATERYAL ve YÖNTEM}

Bambu odun öğütme makinasıyla (Fritsch pulverisette 19) öğütülmüş (Şekil 3), öğütülen bambulardan sokslet ekstraksiyon yöntemiyle sikloheksan (2:1) etanol karışımı kullanılarak çözünebilen safsızlıklar uzaklaştırılmıştır. \%8' lik potasyum hidroksit ile alkali işlem uygulanmış ve daha sonrasında lifler \%10'luk asetik asit çözeltisiyle nötralize edilmiştir. Daha sonra sodyum klorit kullanılarak TAPPI metoduyla ağartma işlemi yapılmıştır. Ağartma işlemi yapılan selülozlara $6.5 \mathrm{M}$ sülfürik asit çözeltisi $60^{\circ} \mathrm{C}^{\prime}$ de 2 saat boyunca uygulanarak selüloz nanokristaller elde edilmiştir. Karakterizasyon için TGA analizi ve FTIR spektroskopisi, optik mikroskop kullanılmıştır.

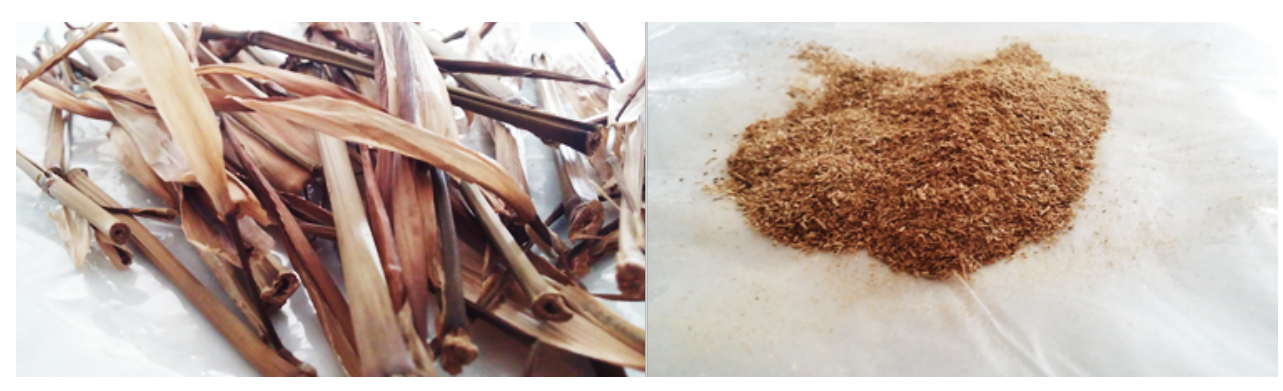

Şekil 3. Fotoğraf (a) işlem görmemiş bambu (b) öğütülmüş bambu

\section{Sokslet Ekstraksiyonu}

Bambu selüloz liflerinden yağsı maddeler ve çözülebilen safsızlıkları ayırmak için $90^{\circ} \mathrm{C}$ 'de 12 saat boyunca sokslet ekstraksiyonu uygulanmıştır. Sokslet ekstraksiyonunda sikloheksan (2:1) etanol karışımı kullanılmıştır (Şekil 4).

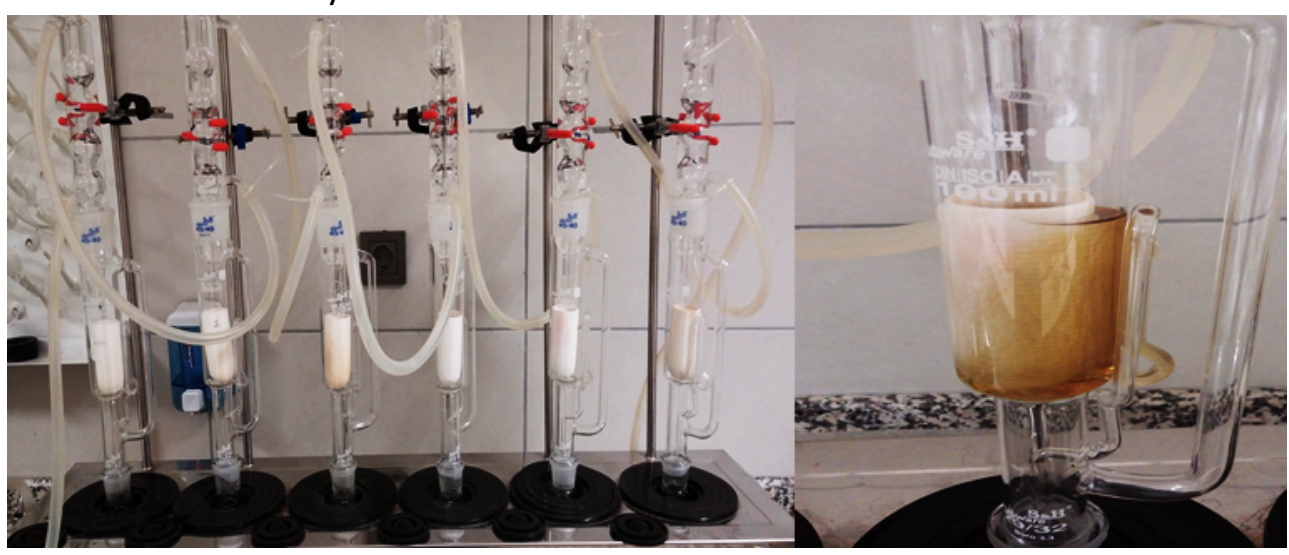

Şekil 4. Sokslet ekstraksiyonu

\section{Potasyum Hidroksit ile Alkali İşlem}

Alkali işlemde \%8'lik potasyum hidroksit $1 \mathrm{~L}$ saf suda çözünmesi sağlanmıştır. Sokslet ekstraksiyon işlemi görmüş toz haldeki bambu \%8 KOH çözeltisine eklenerek $90{ }^{\circ} \mathrm{C}$ 'de manyetik karıştırıcıda 12 saat bekletilmiştir. Daha sonra \%10'luk asetik asit çözeltisiyle süzme işlemi yapılmıştır ve $100^{\circ} \mathrm{C}^{\prime}$ de etüvde bekletilmiştir.

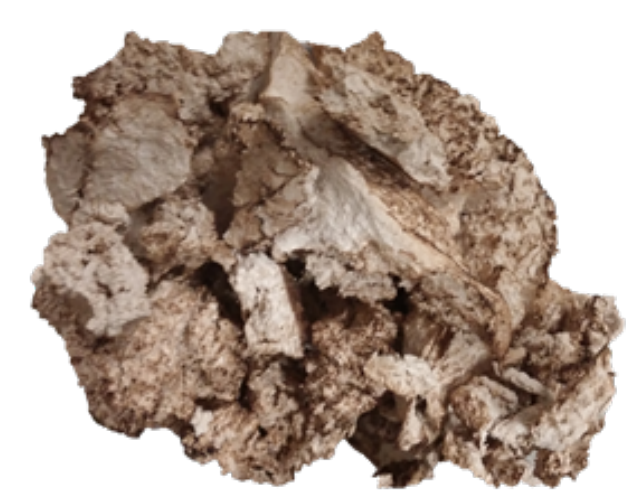

Şekil 5. Alkali işlem sonucu lifler 


\section{Sodyum Klorit ile Ağartma}

Ağartma işlemi TAPPI metodu esas alınarak yapılmıştır. Bu metotta toplam ağırlığı $27,5 \mathrm{~g}$ olan bambu ikiye ayrılmıştır. 14,2 g işlem görmüş bambu liflerine $500 \mathrm{~mL}$ saf su ilave edilerek homojenizatör yardımıyla küçük parçalara ayrılmıştır. Daha sonra manyetik karıştırıcıda $70^{\circ} \mathrm{C}^{\prime}$ de $1000 \mathrm{rpm}$ karıştırılırken saat başı $2,8 \mathrm{~mL}$ asetik asit ve $14,56 \mathrm{~mL}$ sodyum klorit eklenmiştir. Bu işlem 3 saat boyunca uygulanmıştır. Sonrasında karışım oda sıcaklığına düşürüldükten sonra sırasıyla saf su ve aseton ile süzme işlemi gerçekleştirilmiştir.

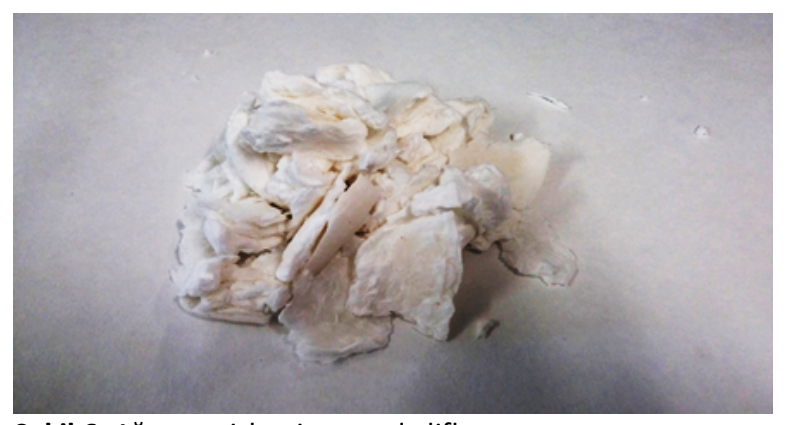

Şekil 6. Ağartma işlemi sonunda lifler

\section{Nanokristal Üretimi}

Ağartma işlemi yapılmış olan 7,4 g bambu selülozu 187,5 $\mathrm{mL}$ sülfürik asit çözeltisi (122,6 mL saf su- $64,9 \mathrm{~mL}$ sülfürik asit) içerisinde $60^{\circ} \mathrm{C}^{\prime}$ de $1000 \mathrm{rpm}$ manyetik karıştırıcıda bekletilmiştir. Uygulama sonunda oda sıcaklığına inildikten sonra karışımın 10 katı kadar soğuk saf su ilave edilmiştir. Analizler için kullanılmak üzere bu karışımdan $36 \mathrm{~mL}$ alınarak santrifüj cihazında (Sigma 1-14 Mikro Santrifüj) 1,5 mL'lik 24 parçaya ayrılmıştır. Santrifüj cihazında $12.000 \mathrm{rpm} 3 \mathrm{dk}$ 'lık periyotlarla 15 defa yıkama işlemi yapılarak pH değeri 5-6 arasına getirilmiştir. Karışımın santrifüjde kullanılmayan büyük kısmı ise filtre kağıdı kullanarak kurutmadan süzme işlemi yapılmış ve $\mathrm{pH}$ 5-6 değerine getirilmiştir (Şekil 7). Süzme işlemi biten nanoselülozlar dolapta $4^{\circ} \mathrm{C}^{\prime}$ de tutulmuştur.

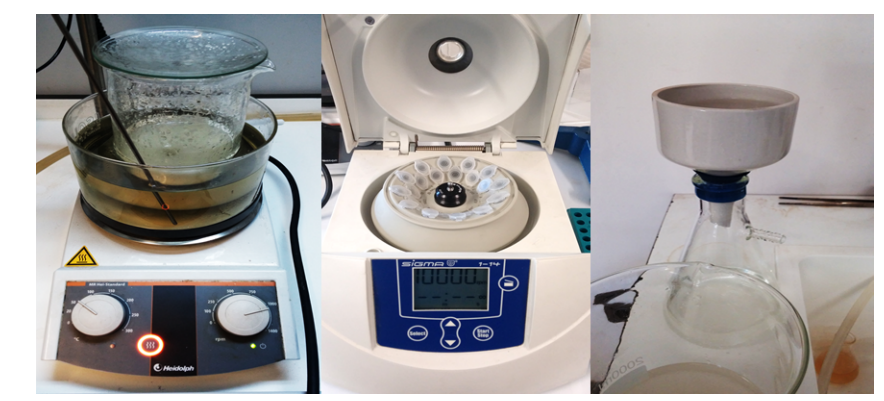

Şekil 7. Nanokristal selüloz elde edilmesi

\section{TGA Ölçümü}

Bambu nanoselülozun termal kararlılı̆ı TGA analizi ile belirlenmiş ve işlem görmemiş bambuyla karşılaştırılmıştır. TGA analizi $30-800{ }^{\circ} \mathrm{C}$ sıcaklıklarında $10^{\circ} \mathrm{C} / \mathrm{dk}$ ısıtma hızında gerçekleştirilmiştir.

\section{FTIR Analizi}

Bambu ve bambudan elde edilen CNC'un kimyasal yapısı ve değişimleri FTIR spektroskopisiyle araştırılmıştır. FT-IR spektrumları için universal ATR aksesuarı olan Brooker marka cihaz kullanılmıştır. Ölçümler $4000-400 \mathrm{~cm}^{-1}$ dalga boyları arasında $4 \mathrm{~cm}^{-1}$ çözünürlükte yapılmıştır.

\section{BULGULAR ve TARTIŞMA}

\section{TGA-DTG ait Bulgular}

Şekil 8'de işlem görmemiş bambu ve bambudan elde edilen nanokristalin selülozun termal bozunma sonucu ağırlık kaybı-sıcaklık grafiği gösterilmiştir. $100^{\circ} \mathrm{C}^{\prime}$ ye kadar olan ağırlık kayıplarının yapıya bağlı olmayan suyun uzaklaşması olarak yorumlanmaktadır. Bundan sonraki ağırlık kayıpları ise piroliz sonucu gerçekleşmektedir. Bambu $250^{\circ} \mathrm{C}-350^{\circ} \mathrm{C}$ bölgesinde bozunurken, selüloz nanolifleri $200^{\circ} \mathrm{C}-400^{\circ} \mathrm{C}$ gibi geniş bir bölgede bozunmakta olup, degradasyonun iki basamakta gerçekleştiği görülmektedir. Nanoselülozların düşük bozunma sıcaklığı bambuya kıyasla küçük lif boyutlarındaki geniş spesifik yüzey alanı olarak yorumlanabilir (Sofla ve ark. 2016). Sülfürik asit ile üretilen $\mathrm{CNF}^{\prime}$ in termal analizde onset sıcaklığı $200^{\circ} \mathrm{C}^{\prime}$ lerde olup bambuya göre ve diğer asit ve yöntemlerle üretilen CNF'lere göre düşüktür (Sofla ve ark. 2016). Bunun sebebinin sülfürik asit ile muamele esnasında yapıya bağlanan sülfat gruplarının, sıcaklıkla birlikte kopması ve genel yapının termal stabilitesini düşürmesi olarak açıklamak mümkündür (Roman ve Winter 2004). Sıcaklıkla yapıdan ayrılan sülfat grupları, ortamdaki asitliği ve reaktiviteyi arttırarak selülozun depolymerizasyonunu hem bazı hidroksil gruplarını bozmasıyla ya da katalizör etkisiyle hızlandırmakta olduğu düşünülmektedir. 


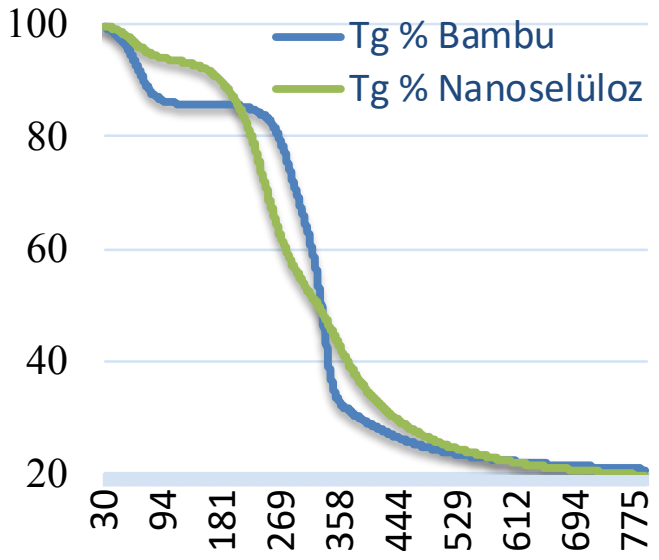

Şekil 8. İşlem görmemiş bambu ve CNC'un TGA ve DTG grafikleri

\section{FTIR Spektroskopisine ait Bulgular}

Şekil 9'da işlem görmemiş bambu ve selüloz nanofibrillerin FTIR spektrası gösterilmiştir. íki örnek de 3200-3500 $\mathrm{cm}^{-1}$ band aralığında çoğunlukla selüloz moleküldeki hidroksil gruplarına ait $\mathrm{O}-\mathrm{H}$ gerilim titreşimi görülmektedir. $2850-2950 \mathrm{~cm}^{-1}$ band aralığı da C-H ve C$\mathrm{H}_{2}$ gerilim titreşimleri olarak bilinmektedir. İşlem görmemiş bambu temel olarak $1600 \mathrm{~cm}^{-1}$ ve $1730-1740$ $\mathrm{cm}^{-1}$ bölgelerinde hemiselüloz ve lignin komponentlerinden kaynaklanan titreşimlere sahiptir. İşlem görmemiş bambudaki $1728 \mathrm{~cm}^{-1}$ bandını oluşturan C-O titreşimi, hemiselüloz ve pektindeki asetil ve üronik ester gruplarından ve lignindeki $p$-kümerik asitlerideki ester bağlantılarında görülmektedir (Li ve ark. 2014). Bu

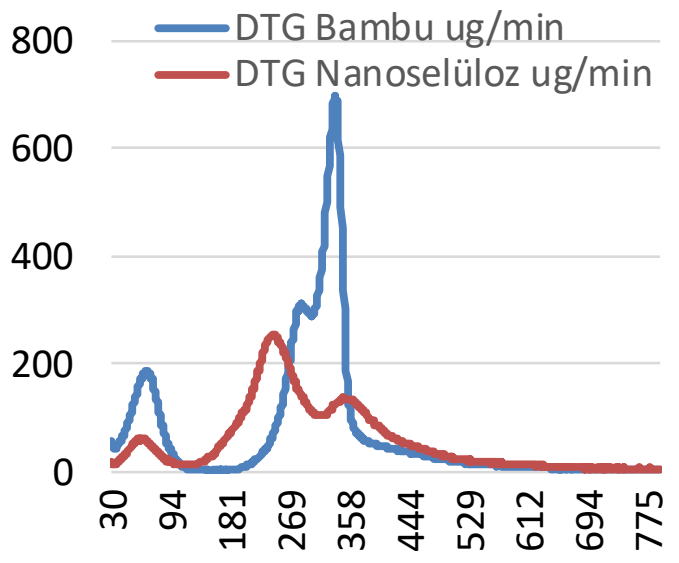

bandın CNF'de tamamen kaybolduğu ortaya çıkmaktadır. Ayrıca işlem görmemiş bambudaki $1604 \mathrm{~cm}^{-1}$ lignin aromatik gruplarındaki $\mathrm{C}$ - $\mathrm{C}$ düzlem için simetrik gerilme titreşimi olarak bilinmekte olup, CNF örneğinde kaybolmuştur (Kumar ve ark. 2012). Bu bandların CNF'de kaybolmaları lignin ve hemiselülozun özellikle kimyasal ekstraksiyon sürecinde uzaklaşması sebebiyle olmuştur.

Selüloz miktarının yüzde olarak arttığını da band yoğunluklarından anlamak mümkündür, özellikle $897 \mathrm{~cm}$ ${ }^{1}$ bandının yoğunluğunun arttığı gözlenmektedir. Bu band selüloz molekülünde glikoz birimleri arasındaki glikozidik bağa ait titreşimden kaynaklanmaktadır.

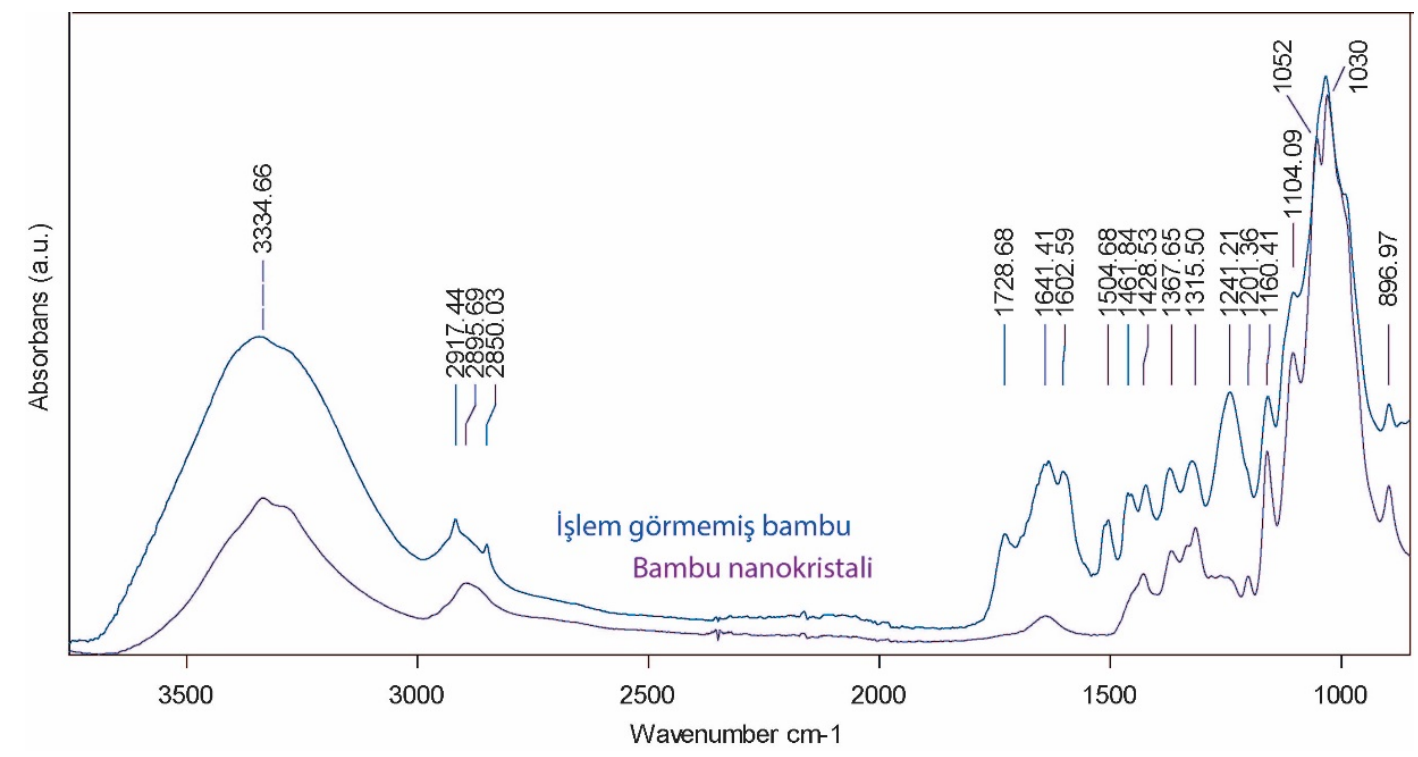

Şekil 9. İşlem görmemiş bambu ve bambu nanofiberlerin FTIR spektroskopisi 


\section{Işık Mikroskobuna ait Bulgular}

Şekil $10^{\prime}$ da selüloz nanofibrillerin ışık mikroskobu altında görüntüsü verilmektedir. $1 \mu \mathrm{m}$ ölçekle verilen resimde görüntü alınabilen birçok lifin çapının ortalama 200 nm olduğu, boylarının ise farklılık göstermekle birlikte 3 $\mu m^{\prime}$ den fazla olduğu anlaşılmaktadır. Ancak farklı bölgelerde başka bölgelerde 2-3 $\mu \mathrm{m}$ çapında 20-30 $\mu \mathrm{m}$ uzunluğunda makrofibrillerin de olduğu görülmüştür. Parçacık boyutlarını kesin olarak belirlemek ve dağılımını ortaya çıkarmak için parçacık boyutu analizi yaptırmak gerektiği görülmüştür.

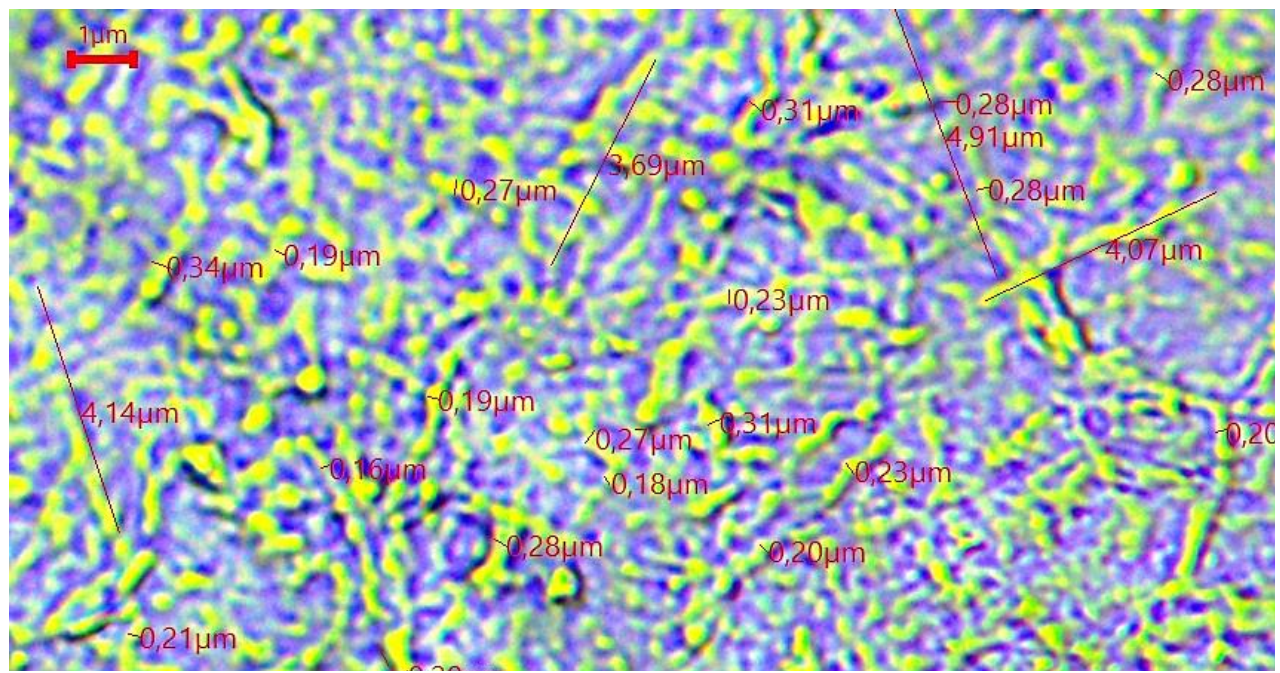

Şekil 10. Selüloz nanofibrillerin ışık mikroskobu altındaki görüntüsü (40x objektif $-1 \mu \mathrm{m}$ ölçek)

\section{SONUÇLAR}

Bu çalışmayla literatürde ilk defa Forgesia nitida bambu türünden sülfürik asitle hidroliz yöntemiyle selüloz nanofibrillerin üretilmiştir. Üretilen nanofibril selüloz termal olarak, kimyasal olarak ve yapısal olarak incelenmiştir. Yapılan analizler sonucunda termal ve kimyasal bulguların literatürle uyumlu bir şekilde olduğu. Termal çıktılara bakıldığında, nanoselüloz hazırlama sürecinde kullanılan sülfürik asit sebebiyle, selüloza bağlanan sülfat gruplarının termal bozunmayı bir miktar hızlandırdığı anlaşılmaktadır. FTIR sonuçlarına göre lignin ve hemiselülozun, selüloz yapısından tamamen uzaklaştığı görülmüştür. Morfolojik analizlere göre de nanofibril çapının ışık mikroskobuyla fark edilebilen ölçekte 190 nm'lere kadar düştüğü görülmüştür. Ancak birçok makrofiberinde gözlemlendiği selüloz ortamında, sonuç olarak yöntemde homojenizasyonu artıracak şekilde iyileştirmeler yapılması gerektiği, ilave olarak asit hidroliz süresinin arttırılmasının gerekli olduğu anlaşılmıştır.

\section{TEŞEKKÜR}

Bu çalışma 4-6 Ekim 2018 tarihinde Bursa Teknik Üniversitesi'nde düzenlenen 4. Uluslararası Odun Dışı Orman Ürünleri Sempozyumunda sunulmuş ve özet metin olarak basılmıştır.

\section{KAYNAKLAR}

Bardak T, Bardak S, Kayahan, K (2016) Orman endüstrisinde nanoteknoloji. Uluslararası Kültürel ve Sosyal Araştırmalar Dergisi (UKSAD) 2:2, 244-253.

Imadi SR, Mahmood I, Kazi AG (2014) Bamboo Fiber Processing, Properties, and Applications, ser. Biomass and Bioenergy içinde. 27-46. Springer, Cham, Switzerland.

Jain S, Kumar R ve Jindal UC (1999) Mechanical behaviour of bamboo and bamboo composite. Journal of Material Science 27:17, 45984604.

Kumar A, Negi YS, Bhardwaj NK, Choudhary V (2012) Synthesis and characterization of methylcellulose/PVA based porous composite. Carbohydrate Polymers 88:4, 1364-1372.

Li W, Wu Q, Zhao X, Huang Z, Cao J, Li J, Liu S (2014) Enhanced thermal and mechanical properties of PVA composites formed with filamentous nanocellulose fibrils. Carbohydrate Polymers 113, 403-410.

Nelson K, Retsina T, lakovlev M, Heiningen A, Deng $Y$, Shatkin JA, Mulyadi A (2016) American Process: Production of Low Cost Nanocellulose for Renewable, Advanced Materials Applications. Materials Research for Manufacturing içinde, 267-302, Springer Series in Materials Science, vol 224. Springer, Cham. 
Ning L, Dufresne A (2014) Nanocellulose in biomedicine: Current status and future prospect. European Polymer Journal, 59, 302-325.

Pannipa C (2013) Bamboo: An Alternative Raw Material for Wood and Wood-Based Composites. Journal of Materials Science Research 2:2, 90-102.

Parameswaran N, Liese W (1981) The fine structure of bamboo, Editör: Huguchi T, Bamboo production and utilization içinde, Wood Res. Inst., Kyoto Uni., 178-183.

Poyraz B, Arslan R, Akıncı A, Tozluoğlu A. (2018) Modifiye nanoselülozun kimyasal ve morfolojik analizi. Artvin Çoruh Üniversitesi Orman Fakültesi Dergisi 19:1, 39-47.

Razak W, Mohd M, Mohammed S, Mahmud S, Hashim WS, Mohd S, Rasat M, Sukhairi M (2013) Chemical Composition of Four
Cultivated Tropical Bamboo in Genus Gigantochloa. Journal of Agricultural Science 5, 66-75.

Roman M ve Winter WT (2004) Effect of Sulfate Groups from Sulfuric Acid Hydrolysis on the Thermal Degradation Behavior of Bacterial Cellulose. Biomacromolecules 5:5, 1671-1677.

Sofla MRK, Brown RJ, Tsuzuki T ve Rainey TJ (2016) A comparison of cellulose nanocrystals and cellulose nanofibres extracted from bagasse using acid and ball milling methods. Advances in Natural Sciences: Nanoscience and Nanotechnology 7:3, 035004.

Tozluoğlu A, Çöpür Y, Özyürek Ö, Çıtlak S (2015) Nanoselüloz üretim teknolojisi. Türkiye Ormancılık Dergisi 16:2, 203-2019. 